\title{
Related Individuals with Different Androgen Receptor Gene Deletions
}

\author{
Helen E. MacLean, ${ }^{\star}$ Simon Chu, ${ }^{*}$ Garry L. Warne, ${ }^{\star}$ and Jeffrey D. Zajac ${ }^{\star}$ \\ *Centre for Child Growth and Hormone Research, Royal Children's Hospital, Parkville 3052, Australia; \\ and ${ }^{\ddagger}$ Deptartment of Medicine, University of Melbourne, Royal Melbourne Hospital, Parkville 3050, Australia
}

\begin{abstract}
We have identified different members of one family affected by androgen insensitivity syndrome who have deletions of different exons of the $X$-linked androgen receptor $(A R)$ gene. Two affected ( $X Y$ ) siblings have a deletion of exon $E$ of the $A R$ gene and their affected (XY) aunt has a normal exon $E$, but a deletion of exons $F$ and $G$ of the same gene. The mother and maternal grandmother of the children both carry the exon $\mathbf{E}$ deletion, but not the exon F, $G$ deletion. Both deletions are $5 \mathrm{~kb}$ in length and have one breakpoint within a 200-bp region in intron 5; however, they extend in opposite directions. The probability that these two different deletions have arisen at random is extremely low, but the cause of this intriguing phenomenon remains to be found. (J. Clin. Invest. 1993.91:1123-1128.) Key words: androgen receptor $\bullet$ androgen insensitivity syndrome • mutation • DNA transposable element • site-specific mutagenesis
\end{abstract}

\section{Introduction}

The androgen receptor (AR $)^{1}$ belongs to a superfamily of ligand responsive DNA-binding transcription factors that includes the other steroid receptors, the receptors for thyroid hormone, vitamin $\mathrm{D}$, and retinoic acid, as well as a number of so-called "orphan" receptors, such as the chicken ovalbumin upstream promoter, identified by homology to this family, but for which the ligands remain to be found $(1,2)$. Members of this superfamily share both DNA sequence and functional homology. The structure of the androgen receptor, illustrated in Fig. 1, includes the DNA binding and ligand binding domains, which share homology with other members of the superfamily, as well as a variable amino-terminal domain, involved in modulation of transcription activation $(3,4)$.

The AR gene is located on the $\mathrm{X}$ chromosome, at Xq11-12 (5). Mutations in the AR give rise to androgen insensitivity syndrome (AIS), which has a range of clinical presentations. The spectrum includes the complete syndrome, (previously called testicular feminization), in which affected $\mathrm{XY}$ individ-

Address correspondence and reprint requests to Dr. Jeffrey Zajac, Department of Medicine, University of Melbourne, Royal Melbourne Hospital, 3050 Victoria, Australia.

Received for publication 26 May 1992 and in revised form $31 \mathrm{Au}$ gust 1992

1. Abbreviations used in this paper: AIS, androgen insensitivity syndrome; AR, androgen receptor.

J. Clin. Invest.

(c) The American Society for Clinical Investigation, Inc.

0021-9738/93/03/1123/06 \$2.00

Volume 91, March 1993, 1123-1128 uals develop as phenotypic females with female external genitalia, and also includes individuals with ambiguous genitalia, as well as phenotypically normal men who are infertile. A number of reports have identified mutations in the AR gene in patients with complete AIS (for review, see reference 6). These reports include point mutations which define amino acids in the DNA and steroid binding domains absolutely necessary for normal receptor function, premature termination codons, aberrant splicing of mRNA, and one deletion of the entire steroid binding domain of the receptor. These studies indicate the heterogeneity of mutations causing AIS.

We have investigated mutations of the AR gene in one family with complete AIS. This family has three affected members in two generations, two sisters and their maternal aunt. We have identified a deletion of exon $\mathrm{E}$ of the AR gene in the two sisters, and a deletion of exons $F$ and $G$ in their affected aunt.

\section{Methods}

Cell culture. Fibroblasts were cultured from pubic skin biopsies and maintained in Eagle's (basal) medium, $10 \% \mathrm{FCS}$, and $100 \mathrm{IU} / \mathrm{ml}$ penicillin and $100 \mu \mathrm{g} / \mathrm{ml}$ streptomycin. Cells were incubated at $37^{\circ} \mathrm{C}$ in $5 \% \mathrm{CO}_{2}$.

Androgen receptor assay. Fibroblasts were assayed in $4 \times 60-\mathrm{mm}$ dishes, at $80-100 \%$ confluency. Cells were assayed using a modification of our previously published method (7), as follows: Cells were incubated at $37^{\circ} \mathrm{C}$ for $1 \mathrm{~h}$ in serum-free DME, washed in ice-cold PBS, then incubated at $37^{\circ} \mathrm{C}$ for $1 \mathrm{~h}$ with $1.0 \mathrm{nM}\left[{ }^{3} \mathrm{H}\right]$ methyltrienolone ( $\mathrm{R} 1881$ ) in the presence and absence of 1,000-fold excess unlabeled $\mathrm{R} 1881$. Cells were then placed on ice and washed five times with ice-cold Tris buffer ( $20 \mathrm{mM}$ Tris-Cl, $150 \mathrm{mM} \mathrm{NaCl}, 2 \mathrm{mg} / \mathrm{ml} \mathrm{BSA}, \mathrm{pH} 7.4$ ), two times with ice-cold $150 \mathrm{mM} \mathrm{NaCl}$, dried, then solubilized in $0.1 \mathrm{M}$ $\mathrm{NaOH}$. A $500-\mu \mathrm{l}$ aliquot of the cell lysate was counted and protein content was determined using the Lowry method (8). Specific binding was calculated by subtracting the nonspecific from the total binding.

DNA isolation. DNA for PCR was isolated from whole blood and cultured fibroblasts as described (9). DNA for Southern analysis was isolated using the salting-out lysis method (10) followed by phenolchloroform extraction.

Polymerase chain reaction. PCR was carried out using primers covering each exon, as illustrated in Fig. 2, in a reaction mixture containing $200 \mu \mathrm{M}$ dNTPs, $1.0 \mu \mathrm{M}$ each primer, $100 \mathrm{mM}$ Tris-Cl, $\mathrm{pH} 8.3,50$ $\mathrm{mM} \mathrm{KCl}, 1.5 \mathrm{mM} \mathrm{MgCl}_{2}, 0.01 \%$ gelatin, $1 \mu \mathrm{g}$ template DNA and $2 \mathrm{U}$ polymerase (Amplitaq; Cetus Corp., Berkeley, CA). Reactions were carried out in a thermal reactor (Hybaid, Teddington, Middlesex, UK), using the following conditions: 1 cycle of $90^{\circ} \mathrm{C}, 5 \mathrm{~min} ; 60^{\circ} \mathrm{C}, 1 \mathrm{~min}$; $72^{\circ} \mathrm{C}, 6 \mathrm{~min}$ followed by $30-45$ cycles of $90^{\circ} \mathrm{C}, 30 \mathrm{~s} ; 60^{\circ} \mathrm{C}, 1 \mathrm{~min}$; $72^{\circ} \mathrm{C}, 3 \mathrm{~min}$. PCR products were fractionated on $1.4 \%$ agarose gels, stained with ethidium bromide, and visualized under ultraviolet light. Primer sequences, with restriction enzyme sites at the 5 ' end, were modified from Lubahn et al. (11) as follows:

Al 5' AACGATCGCCTGTTGAACTCTTCTGAGC,

\section{A2 5' CCAGATCTGTGAAGGTTGCTGTTCCTCA,}

A3 5' ATAGTCGACAGGCTACCTGGTCCTGGAT, 
A
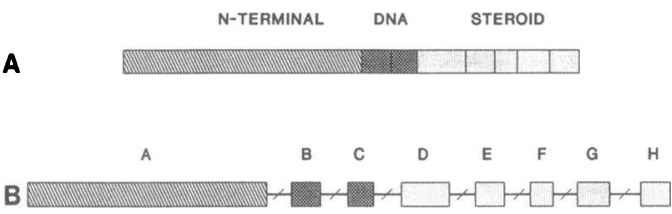

Figure 1. Structure of AR protein and gene. The AR protein $(A)$ has three domains, the amino-terminal, DNA-binding and steroid-binding domains. Eight exons $(B)$ encode the $A R$ protein. Exon $A$ encodes the amino terminal domain, exons $B$ and $C$ encode the DNA-binding domain, and exons B-H the steroid binding domain. The coding region of the gene is $\sim 2.5 \mathrm{~kb}$, the length of the gene including introns is $\sim 90 \mathrm{~kb}$.

A4 5' GAAGATCTGCCTTACACAACTCCTTGGC, A5 5' GTGGATCCCACTTCCTCCAAGGACAATT, A6 5' AATCTAGAGGGTTCTCCAGCTTGATGCG, A7 5' GTCTGCAGAGTCGCGACTACTACAACTT, A8 5' TAAGATCTGGGATAGGGCACTCTGCTCA, A9 5' ATGTCGACTTCACCGCACCTGATGTGTG, A10 5' TTCTGCAGAACACAGAGTGACTCTGCCC, B1 5' ATCTGCAGCCTGCAGGTTAATGCTGAAGA, B2 5' CCGGATCCTAAGTTATTTGATAGGGCCTTG,

C1 5' AGAAGCTTTGGTGCCATACTCTGTCCAC,

C2 5' GAGATCTGATGGCCACGTTGCCTATGAA, D1 5' GCCTCGAGTTTAGAGTCTGTGACC,

D2 5' ATGGATCCCCCTTATCTCATGCTCC,

E1 5' GCGAATTCAACCCGTCAGTACCCAGACTGA,

E2 5' ATCTGCAGCTTCACTGTCACCCCATCACCA,

F1 5' GCAGATCTGGGCTTATTGGTAAACTTCC, F2 5' TAGGATCCAGGAGCTGGCTTTTCCCTAA,

G1 5' GCAGATCTTTCAGATCGGATCCAGCT,

\section{G2 5' TAGGATCCTCTATCAGGCTGTTCTCC,}

\section{H1 5' ATCTCGAGGCCACCTCCTTGTCAACCAT,}

\section{H2 5' TTCCGCGGAACATGTTCATGACAGACTG.}

Southern analysis. Southern blots were carried out using standard methods (12). Hybridization buffer included 50\% deionized formamide and $200 \mu \mathrm{g} / \mathrm{ml}$ boiled herring sperm DNA, and $200 \mathrm{ng}$ probe was labeled with ${ }^{32} \mathrm{P}$ using a random primed DNA labeling kit (Boeh-

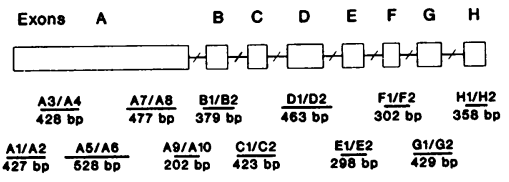

Figure 2. PCR fragments for AR gene. The gene was amplified in 12 separate reactions, with exon $A$ amplified in five overlapping fragments and exons B-H amplified in one fragment each. Primers for exons B-H were homologous to intronic sequences adjacent to the exons (see Methods) to amplify exonic and splice site sequences. ringer Mannheim, Indianapolis, IN). Filters were finally washed in $0.2 \times$ standard saline citrate, $0.1 \%$ SDS at $65^{\circ} \mathrm{C}$. Filters were probed with segments of the human AR cDNA. pCMV-AR (13), an expression vector containing the human AR CDNA, was digested with MboII and EcoRI to yield probe 1, a 450-bp cDNA fragment from exon D to mid exon F, and digested with Pstl and EcoRI to yield probe 2, a 514-bp cDNA fragment from mid exon $\mathrm{F}$ to the noncoding region of exon $\mathrm{H}$ (Fig. $3 A$ ).

\section{Results}

Pedigree of family with AIS. Fig. 4 shows the family, which consists of two affected children, genotypic males but phenotypic females, (III-4 and III-5), their mother, an obligate heterozygote, (II-2), an affected aunt, (II-3), the maternal grandmother, (I-1), and four normal female sisters of II-2 and II-3. The affected children and their aunt have identical clinical features of AIS, including intra-abdominal testes, female external genitalia, short vagina, no uterus, and XY karyotype.

Androgen receptor binding. Androgen receptor binding was measured in genital skin fibroblasts from the three affected relatives and normal male controls. Genital skin fibroblasts were cultured and specific receptor binding measured using the

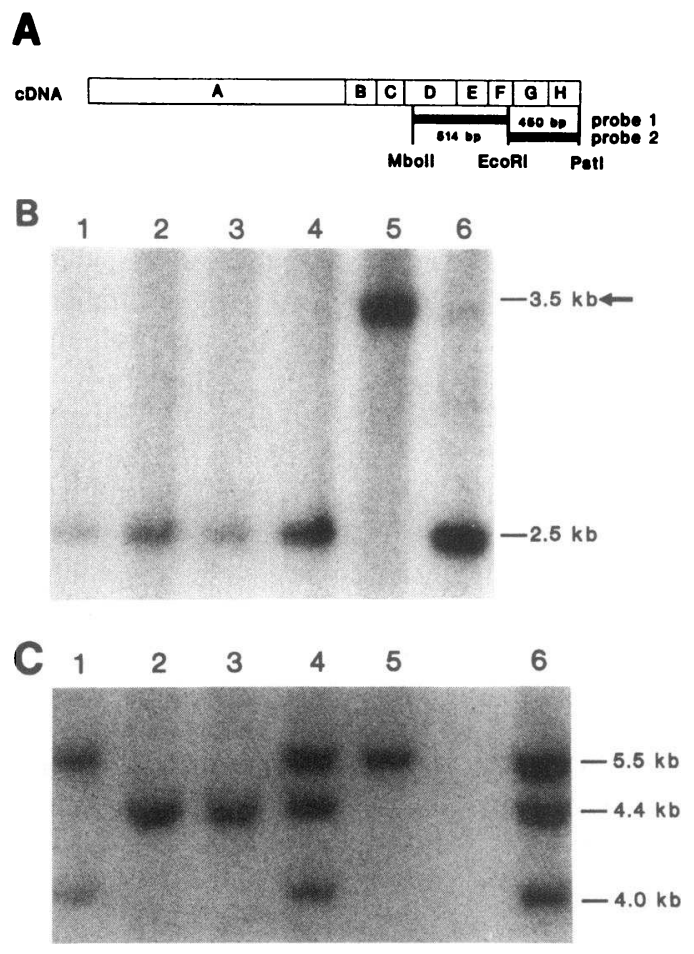

Figure 3. Southern blot analysis of family. In $B$ and $C$, lane 1 contains normal male DNA; lanes 2 and 3 , the affected children (III- 4 and III-5); lane 4, the mother (II-2); lane 5, the aunt (II-3); and lane 6, the grandmother (I-1). $(A)$ Diagram of the human AR cDNA and the two fragments used as probes on Southern blots. Probe 1 is a 514-bp Mboll/EcoRI fragment and probe 2 is a 450-bp EcoR 1 /Pstl fragment. $(B)$ BamHI digest hybridized with probe 2 . The children are normal for this region of the gene, and the abnormal 3.5-kb band in the aunt is indicated with an arrow. $(C)$ Sacl digest hybridized with probe 1 . The mother and grandmother are heterozygotes for the children's mutation, but the aunt has a different banding pattern. 


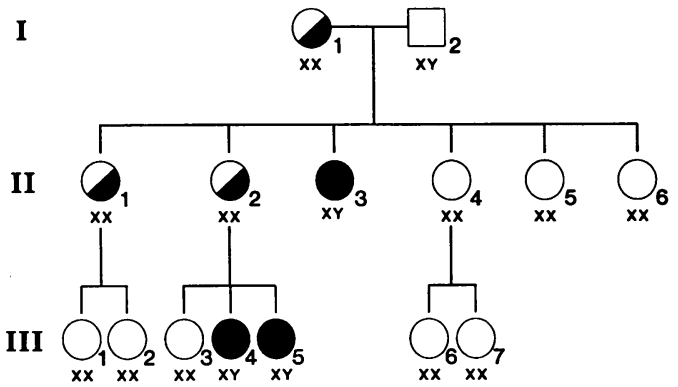

Figure 4. Pedigree of family with receptor negative AIS. The grandmother (I-1) and mother (II-2) are heterozygotes for this trait ( halfshaded circles). The aunt (II-3) and children (III-4 and III-5) are hemizygous affected individuals (shaded circles). A number of normal women are present in generation II and III who have normal female karyotype (46XX). Individual II-1 is a heterozygote, and II-4, II-5, and II-6 are noncarriers ( see text). Note that affected individuals are drawn as female (circles) because they are phenotypic females, even through they are genotypically XY.

synthetic androgen methyltrienolone (R1881). All three affected individuals showed very low binding of R1881 (Fig. 5). The $\left[{ }^{3} \mathrm{H}\right] \mathrm{R} 1881$ bound per milligram protein for the two children (III-4 and III-5) was 4 and $3 \mathrm{fmol}$, respectively, and $3 \mathrm{fmol}$ for the aunt (II-3), (normal range, 24-71 fmol/mg).

Amplification of all exons using PCR. Multiplex PCR was used to amplify all exons of the androgen receptor from the affected and normal individuals. Exon A was amplified in five separate fragments and exons B-H were each amplified in single PCR fragments (Fig. 2). Both hemizygous children had no amplification of exon $\mathrm{E}$, but normal amplification of all other exons. Unexpectedly, the hemizygous aunt had no amplification of exons $F$ and $G$, but normal amplification of all other exons, including exon $\mathrm{E}$. The heterozygous mother and grandmother had normal amplification of all exons, as expected, because both carry one normal AR gene. Fig. 6 shows the PCR products from the family and normal controls for exons $\mathrm{D}$ and $\mathrm{B}(6 A)$, exons $\mathrm{G}$ and $\mathrm{E}(6 B)$, and exons $\mathrm{C}$ and $\mathrm{F}(6 C)$. Each PCR was carried out at least 12 times, using DNA from both blood and cultured fibroblasts collected independently, and results from blood and fibroblasts were identical in all cases.

A PCR fragment from the $5^{\prime}$ end of exon $E$ to $3^{\prime}$ exon $\mathrm{H}$, spanning the deleted exons, was amplified from the aunt's DNA (Fig. $7 A$ ). The distance between these primers in the normal genome is $\sim 7.5 \mathrm{~kb}$ (Fig. $7 \mathrm{~B}$ ), and no fragment could

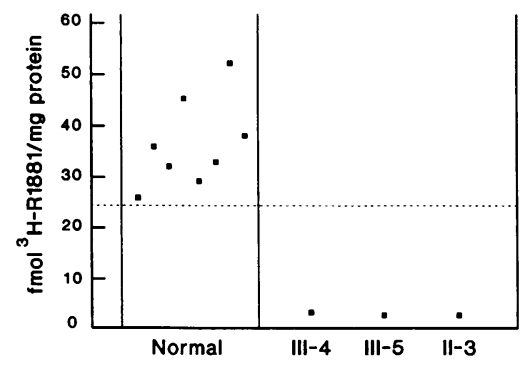

Figure 5. Specific androgen binding in cultured genital skin fibroblasts. Eight normal samples, the affected children (III-4 and III5) and the aunt (II-3) are shown. The normal range of binding is between 24 and $71 \mathrm{fmol}$ ${ }^{3} \mathrm{HR} 1881 / \mathrm{mg}$ protein, and the children and aunt have very low levels of binding.
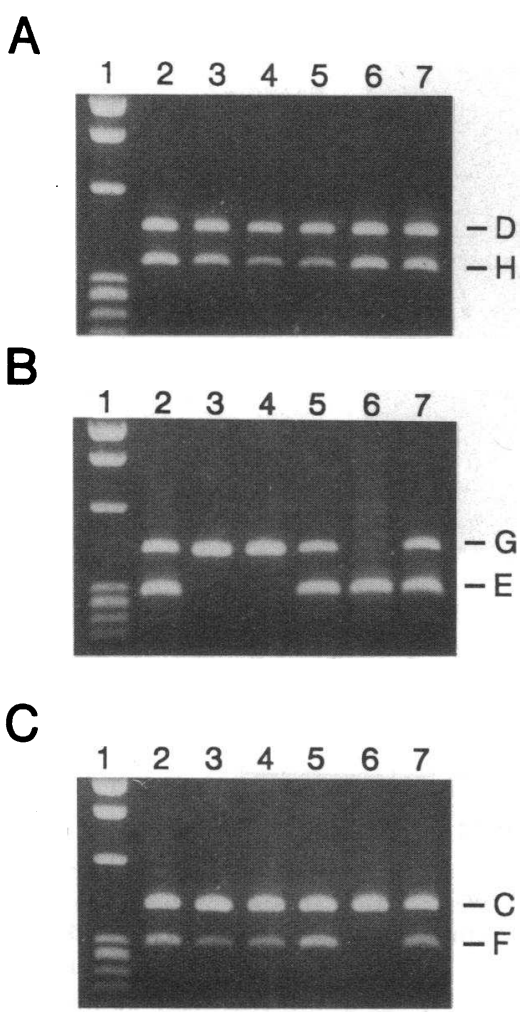

Figure 6. Multiplex PCR products. PCR products amplified from the family and normal controls, fractionated on $1.4 \%$ agarose gels. In each panel, lane $I$ contains the DNA size standard $\phi \times 174$ digested with HaellI, lane 2 contains the normal male control; lanes 3 and 4 , the two affected children (III-4 and III$5)$; lane 5 , their mother (II-2); lane 6, the affected aunt (II-3); and lane 7, the grandmother (I-1). (A) Exons D (463 bp) and B (379 bp) present in all individuals. $(B)$ Exon $\mathrm{G}$ (429 bp) deleted in the aunt and exon E ( 298 bp) deleted in the two children. $(C)$ Exon $\mathrm{C}$ $(423 \mathrm{bp})$ present in all individuals and exon F (302 bp) deleted in the aunt.

be amplified from normal samples, but a $2.5-\mathrm{kb}$ specific PCR fragment was amplified from the aunt. This indicates that she has $\sim 5 \mathrm{~kb}$ of DNA deleted between primers $\mathrm{E} 1$ and $\mathrm{H} 2$. The grandmother and all normal females in generation II had no amplification of this fragment, indicating that none of them carry this deletion. Sequence analysis confirmed that this 2.5 $\mathrm{kb}$ fragment includes all the normal sequence of exons $\mathrm{E}$ and $\mathrm{H}$ (data not shown ). It was not possible to amplify a PCR product spanning the exon $\mathrm{E}$ deletion of the children. The distance from exon $\mathrm{D}$ to exon $\mathrm{F}$ is $\sim 10.9 \mathrm{~kb}$, too large to be amplified even if it contained a large deletion.

The 2.5-kb E1/H2 PCR product from the aunt indicates that her mutation is a deletion, and is not caused by a mutation in the hybridization site of one or more of the PCR primers. It also rules out the possibility that the failure of exons to amplify was caused by translocations that had breakpoints in the middle of these exons. Southern analysis on the aunt's DNA (see next section ) also confirms this. Southern analysis also indicates that the children's mutation is also a deletion, and not caused by a translocation or primer hybridization mutation.

Southern analysis localizes deletions. Southern blotting was carried out using exon-specific probes generated by digests of AR cDNA (Fig. $3 A$ ). For each restriction enzyme used in the Southern blots, at least five separate filters were analyzed. DNA digested with BamHI and hybridized with probe 2 showed a $2.5-\mathrm{kb}$ band in control samples (Fig. $3 \mathrm{~B}$, lane 1 ), the same band in the children, who are normal in this region of the gene (lanes 2 and 3), but a 3.5-kb band in the aunt, lane 5, indicated with arrow. The mother and grandmother (lanes 4 and 6 ) had only the $2.5-\mathrm{kb}$ band, but not the $3.5-\mathrm{kb}$ band, meaning that neither of them carry the aunt's mutation.

Sacl digests hybridized with probe 1 (Fig. $3 C$ ) identified 

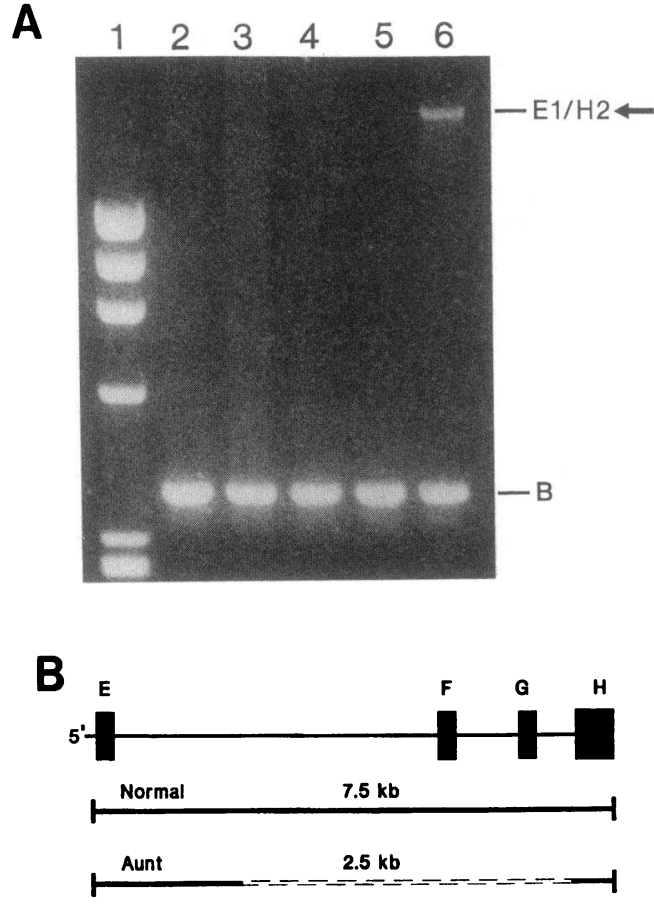

Figure 7. Amplifying across the exon $\mathrm{F}, \mathrm{G}$ deletion in the aunt. $(A)$ Exon B (control) and $\mathrm{E} 1 / \mathrm{H} 2$ amplified from normal male control, lane 1 ; the 2 children (III-4 and III-5), lanes 3 and 4 ; the mother (II2 ), lane 5; and aunt (II-3), lane 6 . The arrow indicates the $2.5-\mathrm{kb}$ E1/H2 band amplified from the aunt's DNA. (B) Diagram of the $3^{\prime}$ end of the AR gene in the normal genome and the aunt. The distance between $\mathrm{E} 1$ and $\mathrm{H} 2$ is $\sim 7.5 \mathrm{~kb}$ in the normal gene, and $2.5 \mathrm{~kb}$ in the aunt. Deleted sequence in the aunt is indicated by the dashed line.

bands of 5.5 and $4.0 \mathrm{~kb}$ in the normal control, a 4.5-kb band in both children, and all three bands in their mother (lane 4), confirming that she is a heterozygote for the children's exon $\mathrm{E}$ deletion. The grandmother also showed the $5.5-\mathrm{kb}, 4.0-\mathrm{kb}$, and the $4.5-\mathrm{kb}$ bands, indicating that she is also a heterozygote for the exon $\mathrm{E}$ deletion. The aunt showed only the 5.5-kb band, and another very large band was unresolvable from the undigested DNA.

From restriction analysis, based on the published restriction map of the AR gene (14), we calculate that the size of the exon $\mathrm{E}$ deletion in the children, mother, and grandmother is $\sim 5 \mathrm{~kb}$. This deletion includes all of exon $\mathrm{E}$, and has one breakpoint $3^{\prime}$ to the HindIII restriction site in intron 4 , and extends into intron 5 , with the other breakpoint immediately $5^{\prime}$ of the Sacl site in this intron (Fig. 8). The size of the exon F, G deletion in the aunt is also $\sim 5 \mathrm{~kb}$. This deletion includes all of exons $F$ and $G$, includes the EcoRI restriction site in intron 7 , and extends into intron 5 , once again to immediately $5^{\prime}$ of the Sacl restriction site. Both the exon $\mathrm{E}$ and the exon F, G deletions have one break point in intron 5, within a 200-bp region, and the deletions cover $\sim 5 \mathrm{~kb}$ of DNA each, in opposite directions.

Southern analysis carried out on the normal females in generation II indicates that individual II- 1 is a heterozygote for the children's deletion, with one normal gene and one gene with exon $\mathrm{E}$ deleted (data not shown). Her two XX daughters have not yet been tested. The other women in generation II (II-4, II-5 and II-6) are not carriers of the exon E deletion. None of

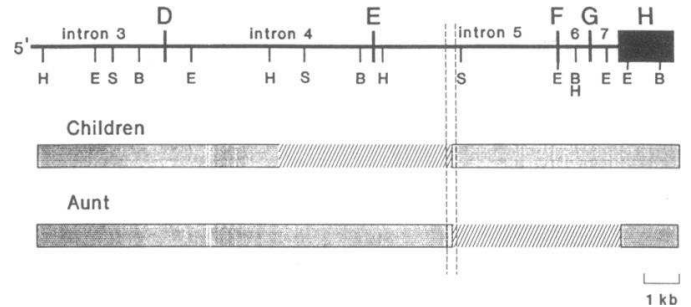

Figure 8. Localization of deletions from southern analysis. Diagram shows 3 ' end of AR gene. Deletions in the children and aunt are indicated by hatching, and the region of the breakpoint in intron 5 is indicated with lines. $B$, BamHI; $E$, EcoRI; $H$, HindIII; $S$, Sacl.

the individuals in generation II except for the affected aunt carry the exon $\mathrm{F}, \mathrm{G}$ deletion.

\section{Discussion}

We have identified two different exonic deletions of the AR gene in different members of one family. Two affected sisters and their heterozygote mother, aunt, and grandmother have a 5-kb deletion of exon $\mathrm{E}$ and surrounding introns. An affected (XY) aunt has exon E present, but a 5-kb deletion of exons $\mathrm{F}$ and $G$ and surrounding intronic sequence. Both deletions have one breakpoint in the same 200-bp region of intron 5, but they extend in opposite directions (Fig. 8). Thus, in five individuals the deleted region is upstream from the common breakpoint, while in another individual, the deletion is downstream. Exons $E, F$, and $G$ all code for the steroid binding domain of the receptor.

The deletion of exons $\mathrm{E}$ and $\mathrm{F}, \mathrm{G}$ in the affected individuals is sufficient to explain their receptor negative AIS. Both deletions would alter the reading frame of the downstream exons, resulting in the production of abnormal receptors, lacking vital parts of the steroid binding domain. The inability of the receptor to bind ligand would thus render the target tissues unresponsive to androgens. It is extremely likely that the described AR gene deletions are the cause of the AIS in these individuals.

The significant feature of this family is the fact that there are two different mutations carried by different affected individuals. Both mutations are deletions, are approximately the same size, and have one breakpoint immediately 5' to the SacI restriction site in intron 5 , but they extend in opposite directions in the gene (Fig. 8). The maternal grandmother (I-1) is a heterozygote, with one normal AR gene, and one gene carrying the exon $\mathrm{E}$ deletion. This exon $\mathrm{E}$ deleted gene has been inherited by two of her normal (XX) daughters (II-1 and II-2), and in turn inherited by two of her daughter's affected (XY) children (III-4 and III-5). But the grandmother's affected (XY) daughter (II3 ), who inherited her only $X$ chromosome and AR gene from her mother, did not inherit the exon E deletion. Her AR gene has an exon F, G deletion, not found in any other individuals in generation II, indicating that this new mutation must have arisen in her mother's germ cells.

The probability that two different deletions, in the same region of the same gene, causing the same phenotype, have arisen at random in related individuals is extremely low, and we do not believe this to be the case. We have investigated the question of the maternity of the affected aunt who carries the new mutation, to discount the possibility of a mix-up of babies 


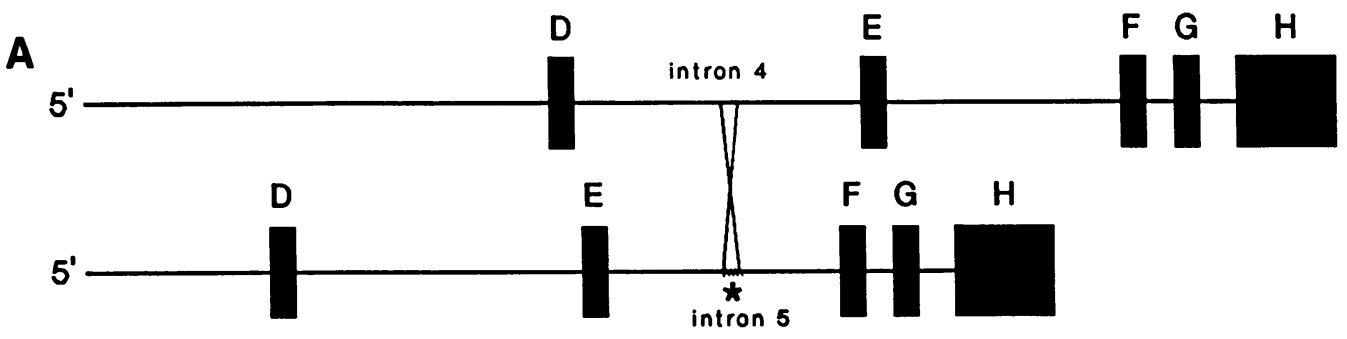

Figure 9. Diagram of putative recombination events. Illegitimate recombination could have caused an exon $\mathrm{E}$ deletion $(A)$ and an exon $\mathrm{F}$, $\mathrm{G}$ deletion $(B)$. The first recombination would have occurred between two normal genes to produce the grandmother's mutation, the second recombination would

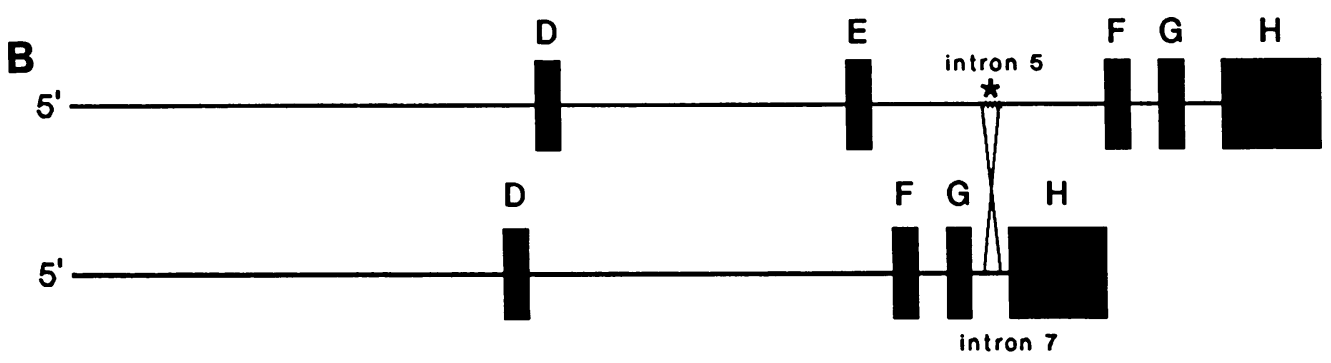
have occurred in the grandmother's germ cells between a normal gene and an exon E deleted gene to produce the aunt's mutation. The putative hot spot in intron 5 , indicated with an asterisk, would have been associated with both recombination events.

in a nursery. The aunt was born in a small country hospital in Tasmania, and we believe the probability of an exchange with another newborn baby also affected with AIS and also with a deletion in the AR gene is infinitesimally small. The affected aunt resembles her mother in appearance, and characterization of blood types for the aunt and her parents is consistent with this maternity (data not shown).

There are a number of potential mechanisms that may explain how this new mutation has arisen. Illegitimate recombination, crossing over between nonhomologous sequences, could have occurred in the grandmother's germ cells between sequences in intron 5 of the normal gene and intron 7 of the exon $E$ deleted gene, producing a gene with exon $E$ present and exons $\mathrm{F}$ and $\mathrm{G}$ deleted. Illegitimate recombination has been reported as producing gene deletions in Fabry disease, associated with 2-6-bp direct repeat sequences (15), and in hemophilia B associated with an Alu repeat (16). It has been shown to be mediated by eukaryotic DNA topoisomerase II in vitro (17), and hotspots for illegitimate recombination have been identified in mouse cells, associated with DNA topoisomerase I and II cleavage sequences $(18,19)$.

However, although illegitimate recombination may be the mechanism causing the exon F, G deletion, this does not explain why it would have occurred in a gene with one deletion already present, nor why both deletions have break points in the same intronic region. The presence of one deletion may cause local disruption of the chromosome and predispose it to further nonhomologous crossing over. It may be that there is a hotspot for illegitimate recombination in intron 5 , perhaps associated with a DNA topoisomerase cleavage site. We postulate that two recombinational events have occurred at this site at different times, producing the two mutations as illustrated in Fig. 9, caused by a predisposition to illegitimate recombination. These individuals may have an abnormality in the enzymes involved in recombination, resulting in a higher than normal frequency of recombination. Interestingly, another branch of this family is affected with familial adenomatous polyposis, a dominantly inherited disease caused by mutations in a recently identified gene on chromosome $5(20,21)$. The grandmother's sister and four of her children have been affected by this disease. It could be that this mutation is also associated with an illegitimate recombination hotspot, and was caused by the same primary defect having effect at more than one locus.

Another hypothesis is the possible existence of a transposon-like element inserted in intron 5 which caused different deletions of adjacent DNA when excised in different cells, thus causing germline mosaicism in the aunt. Transposable elements have been identified in many species, from yeast (22) and maize $(23,24)$ to Drosophila $(25,26)$ and mice $(27)$, and deletions have been identified caused by the excision of adjacent transposable elements (23). Transposon-like sequences have been found in the human genome $(28,29)$, and the first case of a functional element inserted in the Factor VIII gene causing hemophilia $\mathrm{A}$ has recently been reported $(30,31)$. It is possible that a small active transposon was present in intron 5 of the grandmother's DNA, and two different mobilizations occurred in different cell lineages, causing the two deletions. This would account for the fact that both mutations are deletions and are associated with one site in the genome. If this is the explanation, then it would be further evidence for transposition of DNA in humans.

To our knowledge, there have been no reported cases in humans of different members of one family having two different deletions occurring in the same region of the same gene. Although the explanation for this phenomenon remains to be found, it is likely that further analysis of these mutations will lead to fundamental understanding of the mechanism whereby new deletion mutations are generated.

\section{Acknowledgments}

We gratefully acknowledge the donation of the human androgen receptor cDNA by Frank French, Denis Lubahn, and Elizabeth Wilson, The 
Laboratories for Reproductive Biology, University of North Carolina (Chapel Hill, NC). We thank Dr. Fiona Joske for her help in collection of patient samples. We also thank the Royal Children's Hospital Congenital Adrenal Hyperplasia Support Group for the donation of money to purchase the Hybaid Thermal Reactor.

This work was supported by a grant from the National Health and Medical Research Council of Australia, and the Royal Children's Hospital Research Foundation. H. E. MacLean holds a National Health and Medical Research Council Biomedical Postgraduate Scholarship. J. D. Zajac was supported by a D. W. Keir Fellowship, Department of Medicine, Royal Melbourne Hospital, Parkville, Victoria.

\section{References}

1. Evans, R. M. 1988. The steroid and thyroid hormone receptor superfamily. Science (Wash. DC). 240:889-895.

2. O'Malley, B. 1990. The steroid receptor superfamily: more excitement predicted for the future. Mol. Endocrinol. 4:363-369.

3. Lubahn, D. B., D. R. Joseph, M. Sar, J. Tan, H. M. Higgs, R. E. Larson, F. S. French, and E. M. Wilson. 1988. The human androgen receptor: complementary deoxyribonucleic acid cloning, sequence analysis and gene expression in prostate. Mol. Endocrinol. 2:1265-1275.

4. Jenster, G., H. A. G. M. van der Korput, C. van Vroonhoven, T. H. van der Kwast, J. Trapman, and A. O. Brinkmann. 1991. Domains of the human androgen receptor involved in steroid binding, transcription activation and subcellular localization. Mol. Endocrinol. 5:1396-1404.

5. Brown, C. J., S. J. Goss, D. B. Lubahn, D. R. Joseph, E. M. Wilson, F. S. French, and H. F. Willard. 1989. Androgen receptor locus on the human $X$ chromosome: regional localization and description of a DNA polymorphism. Am. J. Hum. Genet. 44:264-269.

6. Griffin, J. E. 1992. Androgen resistance. The clinical and molecular spectrum. N. Engl. J. Med. 326:611-618.

7. Warne, G. L., S. Gyorki, G. P. Risbridger, B. A. K. Khalid, and J. W. Funder. 1983. Fibroblast studies on clinical androgen insensitivity. J. Steroid Biochem. 19:583-586.

8. Lowry, O. H., N. J. Rosebrough, A. L. Farr, and R. J. Randall. 1951. Protein measurement with the Folin phenol reagent. J. Biol. Chem. 193:265275.

9. Higuchi, R. 1989. Simple and rapid preparation of samples for PCR. In PCR Technology. Principles and Applications for DNA Amplification. H. A. Erlich, editor. Stockton Press, New York. 35-36.

10. Miller, S. A., D. D. Dykes, and H. F. Polesky. 1988. A simple salting out procedure for extracting DNA from human nucleated cells. Nucleic Acids Res. 16:1215.

11. Lubahn, D. B., T. R. Brown, J. A. Simental, H. N. Higgs, C. J. Migeon, E. M. Wilson, and F. S. French. 1989. Sequence of the intron/exon junctions of the coding region of the human androgen receptor gene and identification of a point mutation in a family with complete androgen insensitivity. Proc. Natl. Acad. Sci. USA. 86:9534-9538.

12. Sambrook, J., E. F. Fritsch, and T. Maniatis. 1989. Analysis and cloning of eukaryotic genomic DNA. In Molecular Cloning: A Laboratory Manual. 2nd ed. Cold Spring Harbor Laboratory, Cold Spring Harbor, NY. 9.31-9.55.

13. Brown, T. R., D. B. Lubahn, E. M. Wilson, F. S. French, C. J. Migeon, and
J. L. Corden. 1990. Functional characterization of naturally occurring mutant androgen receptors from subjects with complete androgen insensitivity. $\mathrm{Mol}$. Endocrinol. 4:1759-1772.

14. Kuiper, G. G. J. M., P. W. Faber, H. C. J. van Rooij, J. A. G. M. van der Korput, C. Ris-Stalpers, P. Klaassen, J. Trapman, and A. O. Brinkmann. 1989. Structural organization of the human androgen receptor gene. J. Mol. Endocrinol. 2:R1-R4.

15. Kornreich, R., D. F. Bishop, and R. J. Desnick. 1990. $\alpha$-Galactosidase A gene rearrangements causing Fabry disease. J. Biol. Chem. 265:9319-9326.

16. Green, P. M., D. R. Bentley, R. S. Mibashan, and F. Giannelli. 1988. Partial deletion by illegitimate recombination of the factor IX gene in a haemophilia B family with two inhibitor patients. Mol. Biol. \& Med. 5:95-106.

17. Bae, Y.-S., I. Kawasaki, H. Ikeda, and L. F. Liu. 1988. Illegitimate recombination mediated by calf thymus DNA topoisomerase II in vitro. Proc. Natl. Acad. Sci. USA. 85:2076-2080.

18. Sperry, A. O., V. C. Blasquez, and W. T. Garrard. 1989. Dysfunction of chromosomal loop attachment sites: illegitimate recombination linked to matrix association and topoisomerase II. Proc. Natl. Acad. Sci. USA. 86:5497-5501.

19. Vu, H. K., L. Delbecchi, D. Bourgaux-Ramoisy, and P. Bourgaux. 1991. The same mammalian replicon yields distinct recombination products in different cell lines. J. Biol. Chem. 266:9320-9326.

20. Kinzler, K. W., M. C. Nilbert, L.-K. Su, B. Vogelstein, T. M. Bryan, D. B. Levy, K. J. Smith, A. C. Preisinger, P. Hedge, D. McKechnie, et al. 1991. Identifcation of FAP locus genes from chromosome 5q21. Science (Wash. DC). 253:661-664.

21. Nishisho, I., Y. Nakamura, Y. Miyoshi, Y. Miki, H. Ando, A. Horii, K. Koyama, J. Utsunomiya, S. Baba, P. Hedge, et al. 1991. Mutations of chromosome 5q21 genes in FAP and colorectal cancer patients. Science (Wash. DC). 253:665-669.

22. Boeke, J. D., D. J. Garfinkel, C. A. Styles, and G. R. Fink. 1985. Ty elements transpose through an RNA intermediate. Cell. 40:491-500.

23. Britt, A. B., and V. Walbot. 1991. Germinal and somatic products of Mul excision from the Bronze-1 gene of Zea mays. Mol. \& Gen. Genet. 277(2):267276.

24. Levy, A. A., and V. Walbot. 1991. Regulation of the timing of transposable element excision during maize development. Science (Wash. DC). 248:1534-1537.

25. Bryan, G. J., J. W. Jacobson, and D. L. Hartl. 1987. Heritable somatic excision of a Drosophila transposon. Science (Wash. DC). 235:1636-1638.

26. Woodruff, R. C., J. L. Blount, and J. N. Thompson. 1987. Hybrid dysgenesis in Drosophila melanogaster is not a general release mechanism for DNA transpositions. Science (Wash. DC). 237:1206-1218.

27. Heidmann, O., and T. Heidmann. 1991. Retrotransposition of a mouse IAP sequence tagged with an indicator gene. Cell. 64:159-170.

28. Paulson, K. E., N. Deka, C. W. Schmid, R. Misra, C. W. Schindler, M. G. Rush, L. Kadyk, and L. Leinwand. 1985. A transposon-like element in human DNA. Nature (Lond.). 316:359-361.

29. Kazazian, H. H., C. Wong, H. Youssoufian, A. F. Scott, D. G. Phillips, and S. E. Antonarakis. 1988. Haemophilia A resulting from de novo insertion of L1 sequences represents a novel mechanism for mutation in man. Nature (Lond.). 332:164-166.

30. Dombroski, B. A., S. L. Mathias, E. Nanthakumar, A. F. Scott, and H. H Kazazian. 1991. Isolation of an active human transposable element. Science (Lond.). 254:1805-1807.

31. Mathias, S. L., A. F. Scott, H. H. Kazazian, J. D. Boeke, and A. Gabriel. 1991. Reverse transcriptase encoded by a human transposable element. Science (Lond.). 254:1808-1810. 